\title{
Interaction between resource identity and bacterial community composition regulates bacterial respiration in aquatic ecosystems
}

\author{
A. P. F. Pires ${ }^{a}$, A. Caliman ${ }^{a, b}$, T. Laque ${ }^{a}$, F. A. Esteves ${ }^{a, c}$ and V. F. Farjalla ${ }^{a}$ \\ a'Departamento de Ecologia, Instituto de Biologia, Universidade Federal do Rio de Janeiro - UFRJ, \\ CP 68020, CEP 21941-590, Rio de Janeiro, RJ, Brazil \\ bepartamento de Botânica, Ecologia e Zoologia, Centro de Biociências, Universidade Federal do \\ Rio Grande do Norte - UFRN, CP 1524, CEP 59072-970, Natal, RN, Brazil \\ 'Núcleo em Ecologia e Desenvolvimento Socioambiental de Macaé, Universidade Federal do Rio de Janeiro - UFRJ, \\ CP 119331, CEP 27910-970, Macaé, RJ, Brazil \\ *e-mail: farjalla@biologia.ufrj.br
}

Received: May 2, 2014 - Accepted: August 27, 2014 - Distributed: November 30, 2015

(With 2 figures)

\begin{abstract}
Resource identity and composition structure bacterial community, which in turn determines the magnitude of bacterial processes and ecological services. However, the complex interaction between resource identity and bacterial community composition (BCC) has been poorly understood so far. Using aquatic microcosms, we tested whether and how resource identity interacts with $\mathrm{BCC}$ in regulating bacterial respiration and bacterial functional diversity. Different aquatic macrophyte leachates were used as different carbon resources while BCC was manipulated through successional changes of bacterial populations in batch cultures. We observed that the same BCC treatment respired differently on each carbon resource; these resources also supported different amounts of bacterial functional diversity. There was no clear linear pattern of bacterial respiration in relation to time succession of bacterial communities in all leachates, i.e. differences on bacterial respiration between different $\mathrm{BCC}$ were rather idiosyncratic. Resource identity regulated the magnitude of respiration of each BCC, e.g. Ultricularia foliosa leachate sustained the greatest bacterial functional diversity and lowest rates of bacterial respiration in all BCC. We conclude that both resource identity and the BCC interact affecting the pattern and the magnitude of bacterial respiration in aquatic ecosystems.
\end{abstract}

Keywords: bacterial community composition, bacterial respiration, aquatic macrophyte leachate, resource identity, aquatic ecosystems.

\section{A interação entre a identidade do recurso e a composição da comunidade bacteriana regula a respiração bacteriana em ecossistemas aquáticos}

\section{Resumo}

A identidade e a composição do recurso estruturam a comunidade bacteriana, que, por sua vez, determina a magnitude dos processos bacterianos e seus serviços ecológicos. Porém, a complexa interação entre a identidade do recursos e a composição da comunidade bacteriana (CCB) tem sido pouco avaliada até o momento. Utilizando microcosmos aquáticos, nós testamos quando e como a identidade do recurso interage com a CCB na regulação da respiração bacteriana e da diversidade funcional bacteriana. Diferentes lixiviados de macrófitas aquáticas foram utilizados como diferentes fontes de carbono, enquanto que a CCB foi manipulada através de mudanças sucessionais das populações bacterianas em culturas de recrescimento. Nós observamos que tratamentos com a mesma CCB respiraram diferentemente em cada fonte de carbono; diferentes fontes também suportaram diferentes valores de diversidade funcional bacteriana. Não houve padrão linear claro de mudança na respiração bacteriana em relação ao tempo de sucessão das comunidades bacterianas nos lixiviados, i.e. diferenças na respiração bacteriana entre diferentes CCB foram idiossincráticas. A identidade do recurso regulou a magnitude da respiração, em cada CCB, e.g. o lixiviado de Ultricularia foliosa sustentou os maiores valores de diversidade funcional bacteriana e as menores taxas de respiração bacteriana em todas as CCB. Nós concluímos que a identidade do recurso e a CCB interagem afetando o padrão e a magnitude da respiração bacteriana em ecossistemas aquáticos.

Palavras-chave: composição da comunidade bacteriana, respiração bacteriana, lixiviado de macrófitas aquáticas, identidade do recurso, ecossistemas aquáticos. 


\section{Introduction}

Theoretical and empirical evidences have demonstrated that some biological features, such as species community composition, can regulate ecosystem services in a variety of ecosystems (Cardinale et al., 2012). These evidences let to establishment of the "biodiversity and ecosystem functioning" paradigm which received a lot of attention in the ecological literature in the last years (see reviews at Balvanera et al., 2006; Caliman et al., 2010). Bacteria are major components of ecosystems, mineralizing organic matter by respiration or linking the dead organic matter to other species in the food web (Azam et al., 1994; Moore et al., 2004). Some studies have reported that bacterial communities may be functionally redundant; reduction of bacterial diversity may therefore have a less negative effect on ecosystem functioning than similar changes in communities of plants or animals (Comte and del Giorgio, 2010; Reinthaler et al., 2005). However the "biodiversity and ecosystem functioning" paradigm is far less demonstrated for micro- than for macroorganisms (for review see Caliman et al., 2010).

Bacteria may respond rapidly to environmental modifications due to their short generation time, which results in marked changes in BCC throughout time (Laque et al., 2010). Accordingly, the paradigm of "everything is everywhere and the environment selects" suggests that changes on the structure of bacterial community should occur mainly through time by responding to changes in the local environmental conditions. These changes may affect directly the functional traits of bacterial community and, consequently, the processes it performs. Although ecological succession of bacterial community is still poorly understood (but see Fierer et al., 2010), recent studies have shown that some temporal dynamic factors can drive important changes on BCC (Langenheder et al., 2012; Pires et al., 2014). Changes in resource quality are one of the most important factors shaping BCC through time, as selecting organisms better adapted to recalcitrant resources that remain in the later stages of ecological succession (i.e. heterotrophic endogenous succession, see Fierer et al., 2010). Therefore, some resource characteristics, such as the quality and availability of specific carbon compounds, are important factors driving changes in $\mathrm{BCC}$ and bacterial function, mainly by selecting specific bacterial functional traits (Felip et al., 1996; Kominoski et al., 2009). Functional diversity has been documented as an important community parameter which regulates many ecosystem processes (Hulot et al., 2000), and bacterial communities with greater functional diversity should perform a large number of bacterial processes more efficiently (Leflaive et al., 2008).

Aquatic macrophytes are important sources of organic matter for aquatic ecosystems, especially for aquatic bacteria (Stepanauskas et al., 2000; Huss and Wehr, 2004). Macrophyte leachates are mainly composed of labile compounds that favor bacterial growth, such as carbohydrates and amino acids (Anesio et al., 2000). Additionally, the quality and quantity of organic matter leached varies among macrophytes and such differences are more pronounced among macrophytes with different life forms (e.g. floating, emergent, submerged, floating-leaves) (Demars and Edwards, 2008). Different leachates have contrasting effects on microbial community processes (Wehr et al., 1999; Stepanauskas et al., 2000; Farjalla et al., 2009) and resource identity can have strong effects on BCC (Judd et al., 2006; Szabo et al., 2007; Kominoski et al., 2009).

Here, we used laboratory microcosms to test whether and how resource identity interacts with BCC to determine bacterial functional diversity and the efficiency of bacterial processes. We used aquatic macrophyte leachates as different carbon resources, while BCC was manipulated through successional changes of $\mathrm{BCC}$ in batch cultures. Total bacterial respiration was chosen as the response variable because it integrates the bacterial community metabolism throughout the incubation time.

\section{Material and Methods}

\subsection{Bacteria community and aquatic macrophytes sampling}

Aquatic macrophytes and bacterial samples were collected from Cabiúnas lagoon, a humic tropical oligotrophic lagoon located on the coastal plain in the northeast of the Rio de Janeiro State, Brazil $\left(22^{\circ}\right.$ and $22^{\circ} 30^{\prime} \mathrm{S}$ and $41^{\circ} 30^{\prime}$ and $42^{\circ} \mathrm{W}$ ). Cabiúnas lagoon is a shallow freshwater lagoon (mean depth of $2 \mathrm{~m}$ ) with a highly developed littoral zone colonized extensively by several aquatic macrophyte species (Esteves et al., 2008). We used four different macrophyte species with different life forms: Typha domingensis Pers. (emergent), Nymphoides indica Kuntze (floating-leaves), Ultricularia foliosa L. (submersed) and Eichornia crassipes Sw. (floating). These macrophytes greatly differ in their tissue chemistry composition. For instance, while T. domingensis has a high $\mathrm{C}$ : $\mathrm{P}$ ratio, $N$. indica shows lower $\mathrm{C}$ : $\mathrm{P}$ values and high polyphenols concentration (Suhett, 2007). Differences in their leachates were also observed; e.g U. foliosa leachates showed high concentrations of soluble carbohydrates and lower phosphorus concentration than $N$. indica leachates (Suhett, 2007). Previous studies have shown that dissolved organic matter (DOM) from such species strongly affects bacterial respiration and growth (Stepanauskas et al., 2000; Farjalla et al., 2009). Only senescent leaves were collected because DOM leaching is more effective during plant senescence.

\subsection{Extraction of DOM leachates from aquatic macrophytes}

The DOM extraction procedure from aquatic macrophytes was previously described at Farjalla et al. (2009). In summary, macrophyte leaves were washed in the laboratory to remove attached material and dried to constant mass at $60^{\circ} \mathrm{C}$ for $72 \mathrm{~h}$. Dry leaves were ground and added to glass bottles containing sterilized distilled water to allow leaching (autoclaved for $30 \mathrm{~min}$ at $120^{\circ} \mathrm{C}, 1 \mathrm{~atm}$ ). The bottles were kept in the dark for $48 \mathrm{~h}$ at approximately 
$4{ }^{\circ} \mathrm{C}$. Leachates were filtered through $0.7 \mu \mathrm{m}$ pore size filters (GF/F, Whatman), lyophilized and frozen to avoid bacterial growth. Few hours before the start of the experiment, each lyophilized leachate was diluted to approximately $9.5 \mathrm{mg} \mathrm{C} \mathrm{L}^{-1}$ with sterilized distillated water. Final DOC concentrations around $10 \mathrm{mg} \mathrm{L}^{-1}$ are common in Cabiúnas and other coastal lagoons in the area (Farjalla et al., 2002). DOC concentrations were analyzed with a Total Organic Carbon Analyzer (TOC-VCPN, Shimadzu).

\subsection{Temporal manipulation of $B C C$}

Differential adjustments of bacterial populations throughout the time driven by changes in resource quantity and quality were previously observed (Fierer et al., 2010). Here, differences in $\mathrm{BCC}$ were established through different incubation times (i.e. successional time) in bacterial dilution cultures, as previously described in Pires et al. (2014). Briefly, a water sample $(10 \mathrm{~L})$ was collected in Cabiúnas Lagoon and taken immediately to the laboratory. The sample was filtered through $0.7 \mu \mathrm{m}$ filters (GF/F, Whatman), to remove larger organisms, but keeping most bacteria. Part of the filtrate was subsequently filtered through $0.22 \mu \mathrm{m}$ pore size filters (SteriCap filter, Millipore) to remove most bacteria (95\% of total community; Farjalla et al., 2009). Dilution cultures were prepared with $10 \%$ of the $0.7 \mu \mathrm{m}$ filtered water and $90 \%$ of the $0.22 \mu \mathrm{m}$ filtered water. Bacterial cultures referring to different successional times of 120, 240, 288 and $366 \mathrm{~h}$ were prepared in acid-rinsed, heat-sterilized $500 \mathrm{~mL}$ culture flasks. The cultures were kept at controlled temperature $\left(23^{\circ} \mathrm{C}\right)$ in the dark for bacterial re-growth. General differences in $\mathrm{BCC}$ were verified using the denaturating gradient gel electrophoresis technique (DGGE) as were previously showed in Pires et al. (2014). DGGE is a suitable technique to analyze differences in the $\mathrm{BCC}$ of different samples, and it can only capture bacterial operational taxonomic units (OTUs) that jointly determine $>95 \%$ of total abundance in the sample (Muyzer and Smalla, 1998; Loisel et al., 2006). Bacteria was collected on $0.2 \mu \mathrm{m}$ pore size filters (Whatman) and stored at $-20^{\circ} \mathrm{C}$. Bacterial DNA was extracted from the filters using the FastDNA SPIN Kit for soil (BIO101, California, USA), and PCR amplifications were performed using a thermal cycler (Mastercycler ${ }^{\circledR}$, Eppendorf). DGGE was carried out using a Dcode Universal Mutation Detection System (Bio-Rad) at $70 \mathrm{~V}$ and $60^{\circ} \mathrm{C}$ for $16 \mathrm{~h}$ in $0.5 \mathrm{x}$ TAE buffer. Details of the PCR and DGEE procedures can be found in Pires et al. (2014). DGGE analysis showed 16 OTUs in all incubation times; 4 bands were ubiquitous across all incubation times and 2 bands were unique to an incubation time. We observed 11, 13, 9 and 6 bands at 120, 240, 288 and $336 \mathrm{~h}$ treatments, respectively, indicating that different time incubations of the same batch cultures resulted in different patterns of BCC, as we expected (Pires et al., 2014).

\subsection{Experimental design and bacterial respiration measurements}

We established a $4 \times 4$ full-factorial experimental design, with four levels of resource identity (four different macrophyte leachates) and four levels of BCC (cultures grown for 120, 240, 288 and $366 \mathrm{~h}$ ). The controls for each $\mathrm{BCC}$ were established through inoculation of each bacterial community with sterilized distilled water. Each treatment had six replicates and the total experimental design resulted in 120 microcosms (four levels of resource identity and one control $\times$ four levels of $\mathrm{BCC} \times$ six replicates).

The experimental microcosms consisted of $20 \mathrm{~mL}$ sterilized glass vials. The microcosms were incubated with $2 \mathrm{~mL}$ of the bacterial community from each succession time cultures and $18 \mathrm{~mL}$ of the macrophyte leachate (or sterilized distilled water in the controls). Before filling the microcosms, the bottles containing the macrophyte leachates were shaken in order to saturate the leachates with dissolved oxygen. Initial measurements of dissolved oxygen concentration [DO] were performed for each microcosm and the vials were completely sealed to avoid gas exchanges. All the microcosms were kept at $23^{\circ} \mathrm{C}$ and in the dark for 10 days. At the end of the experiment, we measured the final $[\mathrm{DO}]$ in each microcosm. Time-integrated bacterial respiration was calculated by subtracting the initial from the final [DO] for each microcosm correcting this value for oxygen consumption from the average [DO] consumption observed in their respective time control. This procedure was previously tested and gave similar results of continuous measurements of [DO] which would be unviable due to the great number of samples (Amaral et al., 2013). All [DO] measurements were performed with an oxygen probe connected to a pico-amperimeter PA2000 (Unisense A/S, Aahrus).

\subsection{Functional traits of bacterial community}

We used the Biolog EcoPlate ${ }^{\mathrm{TM}}$ method (Biolog Inc., Hayward, CA) to verify: $i$ ) the differences in BFD among different successional times (BCC at 120, 240, 288 and 366 h) and ii) if BFD of these bacterial communities responded to different macrophyte leachates. The Biolog EcoPlate contains 31 different carbon substrates and one negative control (with no carbon substrate) in 32 different wells (see Christian and Lind (2007) for more details). Besides the specific carbon source, each well contains a tetrazolium dye. Bacterial degradation of the specific carbon source in each well results in the respiration-dependent reduction of a tetrazolium dye into formazan, which increases the optical density at $590 \mathrm{~nm}\left(\mathrm{OD}_{590}\right)$ of the solution. Samples from each of the six individual replicates from each treatment were combined into one single sample per treatment for Biolog EcoPlate analysis. The wells of each plate were inoculated with $150 \mu \mathrm{L}$ of each treatment sample and the plates incubated at $23^{\circ} \mathrm{C}$ in the dark. The $\mathrm{OD}_{590}$ was measured by spectrophotometry every $24 \mathrm{~h}$ for 5 days using a Varian Cary 50 Microplate Reader. A positive response (i.e. mineralization of the particular carbon substrate in the well) was defined to be any value greater than 0.25 absorbance units of $\mathrm{OD}_{590}$, after correction for the absorbance of the control well. We used only the maximum $\mathrm{OD}_{590}$ value obtained in the five daily measurements for further analysis. 
The Biolog EcoPlate data were analyzed with an adjusted Shannon-Weaver diversity index, called here the bacterial functional diversity (BFD) index. The Shannon-Weaver diversity index is commonly used to describe species diversity, but does not incorporate the number of individuals from each species (Kratz and Frost, 2000). Thus, communities with the same richness and equitability have the same Shannon-Weaver diversity indices, irrespective of the absolute number of individuals of each species. In our data, the maximum $\mathrm{OD}_{590}$ value of each substrate (equivalent of the absolute number of individuals of each species) is important for describing the relative difference in the processes performed among different treatments. Therefore, we used the bacterial carbon uptake in the Biolog EcoPlate as a proxy of a microbial process (i.e. the metabolic capacity to use a specific carbon source) and the respective $\mathrm{OD}_{590}$ as to measure the ability of the community to carry out that process. Higher values of $\mathrm{OD}_{590}$ would represent a greater ability of the bacterial community to mineralize a specific carbon source. The BFD index can be described by the Equation 1:

$$
B F D=-\sum\left(p_{i} \ln p_{i} X_{i} / X_{\max }\right)
$$

where $p_{i}$ is the relative value of $\mathrm{OD}_{590}$ of a given carbon source $i$ in the EcoPlate profile in a specific treatment, $X_{\mathrm{i}}$ is the $\mathrm{OD}_{590}$ value of the source $i$ in the treatment, and $X_{\max }$ is the highest $\mathrm{OD}_{590}$ value of the resource $i$ in all treatments. We calculated the BFD index for all treatments at the beginning and at the end of the incubations for each leachate.

\subsection{Data analysis}

Statistical differences in bacterial respiration rates among treatments were analyzed with a two-way ANOVA followed by a Tukey's post-hoc test. Succession time (BCC) and macrophyte leachates (resource identity) were treated as fixed categorical factors. We used a one-way ANOVA followed by a Tukey's post-hoc tests to verify statistical differences of initial BFD values among different bacterial communities. We performed all the statistical analyses using Statistica ${ }^{\mathrm{TM}}$ StatSoft 7.0 software at a significance level of $\alpha=0.05$.

\section{Results}

BCC and resource identity, as well as their interaction, had significant effects on bacterial respiration $(P<0.05$, two-way ANOVA, Table 1). There was no clear linear pattern of increase (or decrease) of bacterial respiration throughout bacterial time succession (previous incubations of $120,240,288$ and $366 \mathrm{~h}$ in the batch cultures) in the different leachates, i.e. differences in bacterial respiration among different bacterial communities were idiosyncratic (Figure 1, all panels). However, the greatest bacterial respiration rates were usually found at 120 and $288 \mathrm{~h}$ $(P<0.05$, Tukey post-hoc test, Figure 1, all panels). Resource identity regulated the magnitude of respiration of each $\mathrm{BCC}$, i.e. the same $\mathrm{BCC}$ respired differently in each tested carbon resource (Figure 1, all panels). Overall, $U$. foliosa leachate supported the lowest rate of bacterial respiration ( $61.75 \%$ on average among all BCCs; Figure $1 \mathrm{c})$.

Bacterial functional diversity (BFD) was similar among bacterial communities from different successional times, i.e. despite the different BCCs showed in the DGGE analysis (see Material and Methods Section), they did not result in marked differences in bacteria functional capacity of decomposing different carbon sources (Figure 2, initial time, $P>0.05$, Tukey post-hoc test). However, after incubation in different leachates, the BFD index varied greatly among different macrophyte leachates (Figure 2). The leachate of $U$. foliosa supported the highest values of BFD, while the leachates from $N$. indica and $E$. crassipes supported the lowest values of bacterial BFD, considering the different BCCs (Figure 2).

\section{Discussion}

Most of studies in microbial ecology suggest that changes on BCC would not affect bacterial processes because bacterial communities show high functional redundancy (Wertz et al., 2007). However, our results suggest that even a community with the same species composition but with different dominance patterns related to the succession time show significant differences in their ecosystem processes (Figure 1). Heterotrophic aquatic bacteria depend on the uptake of DOC from the media for metabolism. The uptake of organic molecules by bacteria is, in turn, dependent on molecule size and the presence of specific chemical receptors in the external membranes. Low molecular weight carbon compounds (MWCC), such as small carbohydrates and aminoacids, may be directly incorporated into bacterial cells, but high MWCC must be first decomposed by extracellular enzymes to be incorporated (Boucher and Debroas, 2009). Some high MWCC can be fully decomposed by bacterial consortia in which each species produces specific enzymes that break specific atom bonds (Al-Mailem et al., 2010). Despite the predominant presence of carbohydrates and aminoacids, macrophyte leachates also have great amounts of high MWCC (Suhett, 2007). The co-degradation of these compounds by different bacteria was suggested as an important pathway of leached

Table 1. Two-way ANOVA from the effects of resource identity, BCC and their interaction on bacterial respiration.

\begin{tabular}{lcccc}
\hline \multirow{2}{*}{\multicolumn{1}{c}{ Main effect }} & \multicolumn{5}{c}{ Bacterial respiration } \\
\cline { 2 - 5 } & Df & MS & F & P \\
\hline Resource identity & 3 & 3200.5 & 34.558 & $<0.001$ \\
BCC & 3 & 3292.4 & 35.551 & $<0.001$ \\
Resource identity X BCC & 9 & 236.2 & 2.551 & $<0.05$ \\
\hline
\end{tabular}




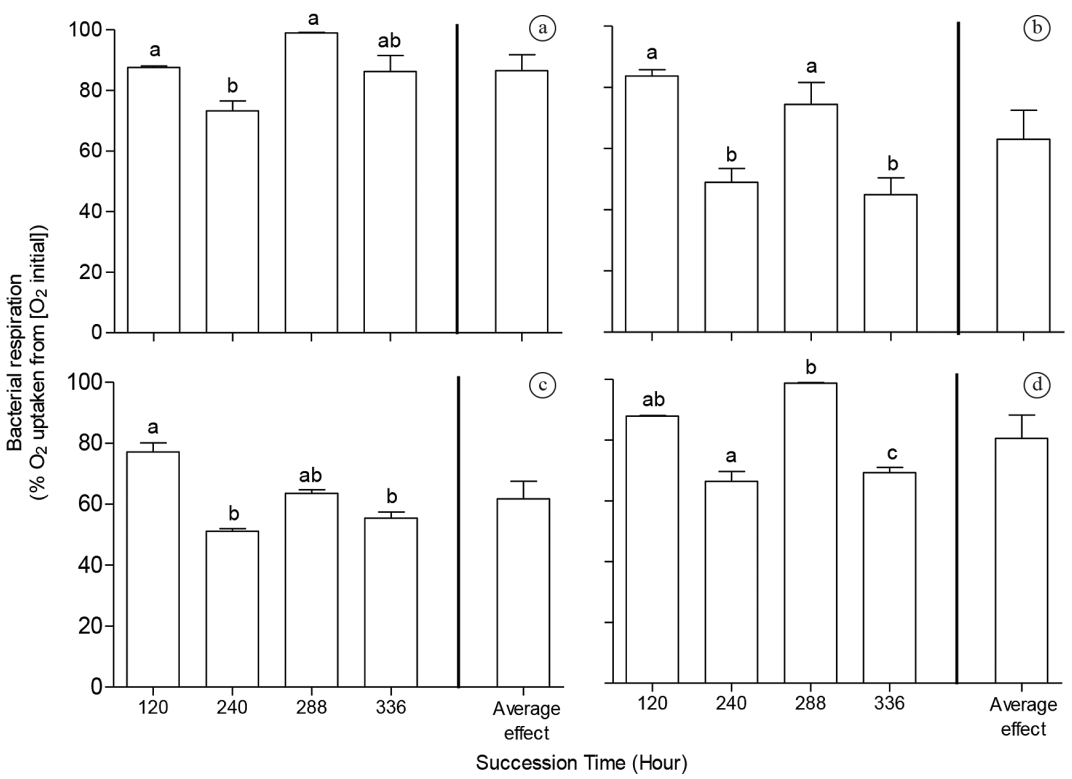

Figure 1. Bacterial respiration $(n=6)$ across different BCC, driven by succession time (incubation-time), when exposed to different macrophyte leachates (resource identity). Leachates from (a) T. domingensis, (b) E. crassipes, (c) U. foliosa and (d) $N$. indica. No significant differences among the average effects of resource identity on bacterial respiration. Different letters represent significant differences among treatments $(P<0.05$, Two-way ANOVA followed by Tukey HSD post-hoc tests).

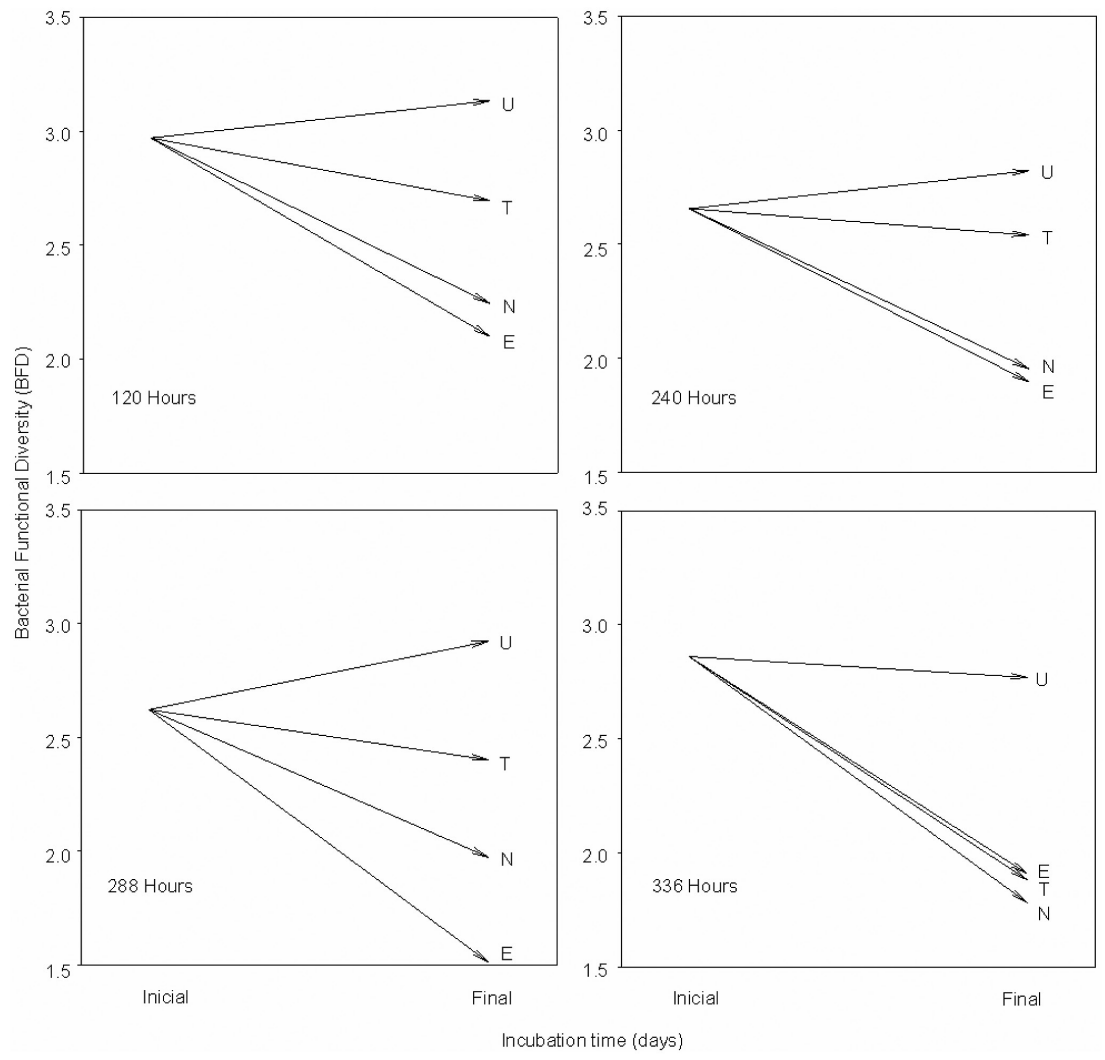

Figure 2. Variation in bacterial functional diversity (BFD) along the different BCC (incubation time 0 ) and after the re-growth on each macrophyte leachate (U. foliosa $(\mathrm{U}), T$. domingensis $(\mathrm{T}), N$. indica $(\mathrm{N})$ and E. crassipes $(\mathrm{E}))$. Initial values are the average of the replicates for bacterial community $(n=3)$, and are not different $(P>0.05$, ANOVA, Tukey post-hoc tests). Final values are the average of the replicates for bacterial community $(n=6)$ after incubation in each leachate. 
DOM-removal in aquatic ecosystems (Farjalla et al., 2009). Therefore, we suggest that the experimental changes on BCC had a direct impact on the bacterial DOM uptake and ultimately on the total respiration rates observed in different bacterial communities.

The change in the proportion of labile carbon compounds to bacteria throughout successional time could be the main driving factor of the $\mathrm{BCC}$, as the labile carbon compounds would be first incorporated by bacteria in the cultures, remaining mainly the most recalcitrant carbon compounds in the later successional times. Bacterial communities in the latter successional times should be more adapted to decompose recalcitrant carbon compounds than the bacterial communities in the earlier ones (Fierer et al., 2010). Therefore, we expected higher bacterial respiration rates in later successional times associated to the higher energetic costs related to the decomposition of recalcitrant carbon compounds than in the earlier ones. However, we observed an idiosyncratic pattern of bacterial respiration in relation to $\mathrm{BCC}$ changes, which highest respiration values were found at 120 and $288 \mathrm{~h}$ (Figure 1). We suggest that species-specific interactions in these successional times could favor the decomposition of some compounds present in the macrophyte leachates, resulting in higher bacterial respiration rates. In the same way, this proposal also explains the fact that the highest bacterial respiration rates were always observed at 120 and $288 \mathrm{~h}$ communities, irrespective to the resource identity. Thus, we suggest that resource identity can regulate the magnitude of bacterial respiration but not the pattern of the relationship between $\mathrm{BCC}$ and the bacterial respiration.

$U$. foliosa is a submerged macrophyte with a poorly developed sustaining tissue, whose leachate shows a greater amount of soluble carbohydrate and it has been shown to enhance some microbial processes, such as microbial respiration (Suhett, 2007). However, in this study, bacterial cultures in U. foliosa leachate showed the lower respiration rates compared to the other treatments (Figure 1). We hypothesize that a large fraction of the $U$. foliosa leachate incorporated by bacterial cells is channeled through anabolic processes and bacterial growth, resulting in low respiration rates and high bacterial growth efficiencies. In fact, bacterial growth efficiencies were higher in leachates from submersed macrophytes, such as $U$. foliosa, than from emerged plants (Farjalla et al., 2009). U. foliosa also supported the highest BFD in all BCC levels, which would favor bacterial uptake and incorporation into biomass of different carbon sources, supporting this hypothesis (Figure 2). These results highlight that resource identity mediates the relationship between the bacterial community and ecosystem processes, possibly through the control of community functional traits. In other words, a resource that sustains a high BFD may increase bacterial performance. In humic-rich DOM ecosystems, like Cabiúnas lagoon, macrophyte leachates stimulated bacterial production and consumption of accumulated humic DOM (Farjalla et al., 2009). Based on our results, we suggest that bacterial production occurs through the maintenance of a high BFD by the input of fresh-labile leachated DOM in these ecosystems.

On the other hand, the great versatility of the bacterial community can hide potential effects of distinct macrophyte leachates, resulting in similar bacterial respiration rates among cultures with different leachates and succession time communities. The degree of functional redundancy was shown as an important community trait explaining the effects of bacterial community on ecosystem functions. For instance, high functional redundancy of bacterial communities was directly related to the maintenance of decomposition rates in soil and aquatic ecosystems (Reinthaler et al., 2005; Wertz et al., 2007). Therefore, in species-poor communities, functional redundancy and versatility may be important factors maintaining the magnitude of bacterial processes. In our study, bacteria communities created from different succession times did not result in significant initial differences in BFD values (Figure 2). However, resource identity seems to be an important factor determining bacterial functional traits, despite its functional versatility. We suggest that in situations where environmental factors may reduce the performance of bacterial community, resource identity can maintain the ecosystem functioning through functional control of bacterial community.

The bacterial community plays an important role in many ecosystem processes. Also, due to its small size and fast growth rates, bacterial communities are useful for testing many ecological questions (Prosser et al., 2007), such as the effects of temporal community changes on the ecosystem processes. Particularly, the functional traits of bacterial communities can play a major role on this relationship (Comte and del Giorgio, 2010). Our results emphasize how the pattern and magnitude of bacterial processes are dependent on BCC and resource identity, respectively. However, the outcome of both factors on the bacterial respiration is rather unpredictable (idiosyncratic pattern) due to specific features of the resources per se, the bacterial communities (e.g. functional redundancy of bacterial species) and the nature of the bacterial species interactions. The understandings about the complex temporal dynamics of bacterial communities are urgent to ensure the maintenance of bacterial services. The complexity and interaction among factors that determine the magnitude of ecosystem processes highlights the challenge of building a predictive ecology in a changing world.

\section{Acknowledgements}

A.P.F.P., A.C. and T.L. are grateful to CNPq and CAPES Institutions for post-graduate scholarships. N.A.C. Marino kindly reviewed the early drafts of the manuscript. This work was part of the project "Impact of Global Climate Changes on Tropical Continental Aquatic Ecosystems" coordinated by Dr. Bias M. Faria of the Petrobras Research and Development Center (CENPES). This research was supported by grants from CENPES/PETROBRAS (ANPETRO 9803 to V.F.F.) and CNPq (Project 475961/2007-2 to V.F.F.). CNPq also provided a research productivity scholarship to V.F.F. 


\section{References}

AL-MAILEM, D.M., SORKHOH, N.A., SALAMAH, S., ELIYAS, M. and RADWAN, S.S., 2010. Oil-bioremediation potential of Arabian Gulf mud flats rich in diazotrophic hydrocarbon-utilizing bacteria. International Biodeterioration \& Biodegradation, vol. 64, no. 3, pp. 218-225. http://dx.doi.org/10.1016/j.ibiod.2010.01.007.

AMARAL, J.H.F., SUHETT, A.L., MELO, S. and FARJALLA, V.F., 2013. Seasonal variation and interaction of photodegradation and microbial metabolism of DOC in black water Amazonian ecosystems. Aquatic Microbial Ecology, vol. 70, no. 2, pp. 157168. http://dx.doi.org/10.3354/ame01651.

ANESIO, A.M., THEIL-NIELSEN, J. and GRANELI, W., 2000. Bacterial growth on photochemically transformed leachates from aquatic and terrestrial primary producers. Microbial Ecology, vol. 40, no. 3, pp. 200-208. PMid:11080378.

AZAM, F., SMITH, D.C., STEWARD, G.F. and HAGSTROM, A., 1994. Bacteria - organic matter coupling and its significance for oceanic carbon cycling. Microbial Ecology, vol. 28, no. 2, pp. 167-179. http://dx.doi.org/10.1007/BF00166806. PMid:24186443.

BALVANERA, P., PFISTERER, A.B., BUCHMANN, N., HE, J.S., NAKASHIZUKA, T., RAFFAELLI, D. and SCHMID, B., 2006. Quantifying the evidence for biodiversity effects on ecosystem functioning and services. Ecology Letters, vol. 9, no. 10, pp. 1146-1156. http://dx.doi.org/10.1111/j.1461-0248.2006.00963.x. PMid:16972878.

BOUCHER, D. and DEBROAS, D., 2009. Impact of environmental factors on couplings between bacterial community composition and ectoenzymatic activities in a lacustrine ecosystem. FEMS Microbiology Ecology, vol. 70, no. 1, pp. 66-78. http://dx.doi. org/10.1111/j.1574-6941.2009.00730.x. PMid:19622070.

CALIMAN, A., PIRES, A.F., ESTEVES, F.A., BOZELLI, R.L. and FARJALLA, V.F., 2010. The prominence of and biases in biodiversity and ecosystem functioning research. Biodiversity and Conservation, vol. 19, no. 3, pp. 651-664. http://dx.doi. org/10.1007/s10531-009-9725-0.

CARDINALE, B.J., DUFFY, J.E., GONZALEZ, A., HOOPER, D.U., PERRINGS, C., VENAIL, P., NARWANI, A., MACE, G.M., TILMAN, D., WARDLE, D.A., KINZIG, A.P., DAILY, G.C., LOREAU, M., GRACE, J.B., LARIGAUDERIE, A., SRIVASTAVA, D.S. and NAEEM, S., 2012. Biodiversity loss and its impact on humanity. Nature, vol. 486, no. 7401, pp. 59-67. http://dx.doi.org/10.1038/nature11148. PMid:22678280.

CHRISTIAN, B.W. and LIND, O.T., 2007. Multiple carbon substrate utilization by bacteria at the sediment-water interface: seasonal patterns in a stratified eutrophic reservoir. Hydrobiologia, vol. 586, no. 1, pp. 43-56. http://dx.doi.org/10.1007/s10750-006-0476-6.

COMTE, J. and DEL GIORGIO, P.A., 2010. Linking the patterns of change in composition and function in bacterioplankton successions along environmental gradients. Ecology, vol. 91, no. 5, pp. 14661476. http://dx.doi.org/10.1890/09-0848.1. PMid:20503878.

DEMARS, B.O. and EDWARDS, A.C., 2008. Tissue nutrient concentrations in aquatic macrophytes: comparison across biophysical zones, surface water habitats and plant life forms. Chemistry and Ecology, vol. 24, no. 6, pp. 413-422. http://dx.doi. org/10.1080/02757540802534533.

ESTEVES, F.A., CALIMAN, A., SANTANGELO, J.M., GUARIENTO, R.D., FARJALLA, V.F. and BOZELLI, R.L., 2008. Neotropical coastal lagoons: an appraisal of their biodiversity, functioning, threats and conservation management. Brazilian
Journal of Biology = Revista Brasileira de Biologia, vol. 68, no. 4, suppl., pp. 967-981. http://dx.doi.org/10.1590/S151969842008000500006. PMid:19197469.

FARJALLA, V.F., FARIA, B.M. and ESTEVES, F.A., 2002. The relationship between DOC and planktonic bacteria in tropical coastal lagoon. Archiv für Hydrobiologie, vol. 156, no. 1, pp. 97-119. http://dx.doi.org/10.1127/0003-9136/2002/0156-0097.

FARJALLA, V.F., MARINHO, C.C., FARIA, B.M., AMADO, A.M., ESTEVES, F.A., BOZELLI, R.L. and GIROLDO, D., 2009. Synergy of fresh and accumulated organic matter to bacterial growth. Microbial Ecology, vol. 57, no. 4, pp. 657-666. http:// dx.doi.org/10.1007/s00248-008-9466-8. PMid:18985269.

FELIP, M., PACE, M.L. and COLE, J.J., 1996. Regulation of planktonic bacterial growth rates: the effects of temperature and resources. Microbial Ecology, vol. 31, no. 1, pp. 15-28. http:// dx.doi.org/10.1007/BF00175072. PMid:24185633.

FIERER, N., NEMERGUT, D., KNIGHT, R. and CRAINE, J.M., 2010. Changes through time: integrating microorganisms into the study of succession. Research in Microbiology, vol. 161, no. 8, pp. 635-642. http://dx.doi.org/10.1016/j.resmic.2010.06.002. PMid:20599610.

HULOT, F.D., LACROIX, G., LESCHER-MOUTOUE, F.O. and LOREAU, M., 2000. Functional diversity governs ecosystem response to nutrient enrichment. Nature, vol. 405 , no. 6784 , pp. 340-344. http://dx.doi.org/10.1038/35012591. PMid:10830961.

HUSS, A.A. and WEHR, J.D., 2004. Strong indirect effects of a submersed aquatic macrophyte, Vallisneria americana, on bacterioplankton densities in a mesotrophic lake. Microbial Ecology, vol. 47, no. 4, pp. 305-315. http://dx.doi.org/10.1007/ s00248-003-1034-7. PMid:15037963.

JUDD, K.E., CRUMP, B.C. and KLING, G.W., 2006. Variation in dissolved organic matter controls bacterial production and community composition. Ecology, vol. 87, no. 8, pp. 2068-2079. http://dx.doi.org/10.1890/0012-9658(2006)87[2068:VIDOMC]2 .0.CO;2. PMid: 16937646 .

KOMINOSKI, J.S., HOELLEIN, T.J., KELLY, J.J. and PRINGLE, C.M., 2009. Does mixing litter of different qualities alter stream microbial diversity and functioning on individual litter species? Oikos, vol. 118, no. 3, pp. 457-463. http://dx.doi.org/10.1111/j.16000706.2008.17222.x.

KRATZ, T.K. and FROST, T.M., 2000. The ecological organization of lake districts: general introduction. Freshwater Biology, vol. 43, no. 3, pp. 297-299. http://dx.doi.org/10.1046/j.13652427.2000.00568.x.

LANGENHEDER, S., BERGA, M., OSTMAN, O. and SZEKELY, A.J., 2012. Temporal variation of beta-diversity and assembly mechanisms in a bacterial metacommunity. The ISME Journal, vol. 6, no. 6, pp. 1107-1114. http://dx.doi.org/10.1038/ismej.2011.177. PMid:22158394.

LAQUE, T., FARJALLA, V.F., ROSADO, A.S. and ESTEVES, F.A., 2010. Spatiotemporal variation of bacterial community composition and possible controlling factors in tropical shallow lagoons. Microbial Ecology, vol. 59, no. 4, pp. 819-829. http:// dx.doi.org/10.1007/s00248-010-9642-5. PMid:20217404.

LEFLAIVE, J., DANGER, M., LACROIX, G., LYAUTEY, E., OUMAROU, C. and TEN-HAGE, L., 2008. Nutrient effects on the genetic and functional diversity of aquatic bacterial communities. FEMS Microbiology Ecology, vol. 66, no. 2, pp. 379-390. http:// dx.doi.org/10.1111/j.1574-6941.2008.00593.x. PMid:18811649. 
LOISEL, P., HARMAND, J., ZEMB, O., LATRILLE, E., LOBRY, C., DELGENES, J.P. and GODON, J.J., 2006. Denaturing gradient electrophoresis (DGE) and single-strand conformation polymorphism (SSCP) molecular fingerprintings revisited by simulation and used as a tool to measure microbial diversity. Environmental Microbiology, vol. 8, no. 4, pp. 720-731. http:// dx.doi.org/10.1111/j.1462-2920.2005.00950.x. PMid:16584483.

MOORE, J.C., BERLOW, E.L., COLEMAN, D.C., DE RUITER, P.C., DONG, Q., HASTINGS, A., JOHNSON, N.C., MCCANN, K.S., MELVILLE, K., MORIN, P.J., NADELHOFFER, K., ROSEMOND, A.D., POST, D.M., SABO, J.L., SCOW, K.M., VANNI, M.J. and WALL, D.H., 2004. Detritus, trophic dynamics and biodiversity. Ecology Letters, vol. 7, no. 7, pp. 584-600. http:// dx.doi.org/10.1111/j.1461-0248.2004.00606.x.

MUYZER, G. and SMALLA, K., 1998. Application of denaturing gradient gel electrophoresis (DGGE) and temperature gradient gel electrophoresis (TGGE) in microbial ecology. Antonie Van Leeuwenhoek International Journal of General and Molecular Microbiology, vol. 73, no. 1, pp. 127-141. http://dx.doi. org/10.1023/A:1000669317571. PMid:9602286.

PIRES, A.P.F., GUARIENTO, R.D., LAQUE, T., ESTEVES, F.A. and FARJALLA, V.F., 2014. The negative effects of temperature increase on bacterial respiration are independent of changes in community composition. Environmental Microbiology Reports, vol. 6, no. 2, pp. 131-135. http://dx.doi.org/10.1111/1758-2229.12143. PMid:24596285.

PROSSER, J.I., BOHANNAN, B.J.M., CURTIS, T.P., ELLIS, R.J., FIRESTONE, M.K., FRECKLETON, R.P., GREEN, J.L., GREEN, L.E., KILLHAM, K., LENNON, J.J., OSBORN, A.M., SOLAN, M., VAN DER GAST, C.J. and YOUNG, J.P.W., 2007. Essay - The role of ecological theory in microbial ecology. Nature Reviews: Microbiology, vol. 5, no. 5, pp. 384-392. http://dx.doi. org/10.1038/nrmicro1643. PMid:17435792.
REINTHALER, T., WINTER, C. and HERNDL, G.J., 2005. Relationship between bacterioplankton richness, respiration, and production in the southern North Sea. Applied and Environmental Microbiology, vol. 71, no. 5, pp. 2260-2266. http://dx.doi. org/10.1128/AEM.71.5.2260-2266.2005. PMid:15870310.

STEPANAUSKAS, R., FARJALLA, V.F., TRANVIK, L.J., SVENSSON, J.M., ESTEVES, F.A. and GRANELI, W., 2000. Bioavailability and sources of DOC and DON in macrophyte stands of a tropical coastal lake. Hydrobiologia, vol. 436, no. 1-3, pp. 241-248. http://dx.doi.org/10.1023/A:1026537905947.

SUHETT, A.L., 2007. Efeitos da biodiversidade de macrófitas aquáticas sobre sua decomposição. Rio de Janeiro: Universidade Federal do Rio de Janeiro, 97 p. Masters Dissertation in Ecology.

SZABO, K.E., ITOR, P.O.B., BERTILSSON, S., TRANVIK, L. and EILER, A., 2007. Importance of rare and abundant populations for the structure and functional potential of freshwater bacterial communities. Aquatic Microbial Ecology, vol. 47, pp. 1-10. http:// dx.doi.org/10.3354/ame047001.

WEHR, J.D., PETERSEN, J. and FINDLAY, S., 1999. Influence of three contrasting detrital carbon sources on planktonic bacterial metabolism in a mesotrophic lake. Microbial Ecology, vol. 37, no. 1, pp. 23-35. http://dx.doi.org/10.1007/s002489900127. PMid:9852520.

WERTZ, S., DEGRANGE, V., PROSSER, J.I., POLY, F., COMMEAUX, C., GUILLAUMAUD, N. and LE ROUX, X., 2007. Decline of soil microbial diversity does not influence the resistance and resilience of key soil microbial functional groups following a model disturbance. Environmental Microbiology, vol. 9, no. 9, pp. 2211-2219. http://dx.doi.org/10.1111/j.14622920.2007.01335.x. PMid:17686019. 